\title{
Perbandingan Karakteristik Asap Cair Pada Berbagai Grade Dari Pirolisis Batubara
}

Rendi Yuli Saputra ${ }^{1}$, M. Naswir ${ }^{2}$, dan Hadistya Suryadri ${ }^{3}$

1,3Program Studi Teknik Kimia, Fakultas Teknik, Universitas Jambi, Muaro Jambi, Indonesia

${ }^{2}$ Program Studi Pendidikan Kimia, Fakultas Keguruan dan Ilmu Pendidikan, Universitas Jambi, Muaro Jambi, Indonesia

Email: rendiyulisaputra60@gmail.com, m.naswir@yahoo.com, hadistya.suryadri@gmail.com

\section{Info Artikel}

Diterima: 12 Maret 2020

Disetujui: 19 Desember

2020

Dipublikasikan: 30

Desember 2020

Alamat Korespondensi:

hadistya.suryadri@gmail.c om

Copyright (c) 2020 Jurnal Engineering

This work is licensed under the Creative Commons Attribution International License (CC BY 4.0).

\begin{abstract}
Abstrak
Asap cair yang dibuat dari proses pirolisis batubara jenis sub-bituminous dilakukan pada temperatur $280-300^{\circ} \mathrm{C}$ dengan waktu pirolisis selama 4,5 jam. Selanjutnya dilakukan 2 jenis pemurnian yaitu metode distilasi dan adsorpsi untuk menentukan metode yang paling efektif dalam mendapatkan asap cair grade 1 , grade 2 dan grade 3. Diketahui bahwa distilasi merupakan metode yang paling efektif dimana pada proses ini didapatkan persen yield pada grade 3 sebesar 92,5\%, grade 2 sebesar $92 \%$ dan grade 1 sebesar 97,22\%. Hal ini dibuktikan pula dengan analisis menggunakan GC-MS didapatkan bahwa asap cair batubara memiliki kadar asam asetat dan kadar fenol yang tinggi dan kandungan senyawa-senyawa ini berperan penting pada proses pengawetan dan antimikroba.
\end{abstract}

Kata kunci: Asap Cair; Batubara; Pirolisis

\begin{abstract}
:
Liquid smoke which is made from sub-bituminous coal pyrolysis is carried out at $280-300^{\circ} \mathrm{C}$ for 4,5 hours. The methods for purification liquid smoke are distillation and adsorption. Both methods were carried out to be selected the most effective way to obtain $1^{\text {st }}$ grade, $2^{\text {nd }}$ grade and $3^{\text {rd }}$ grade of liquid smoke. It was found that $\%$ yield $3^{\text {rd }}$ grade of liquid smoke is $92,5 \%$, \% yield of $2^{\text {nd }}$ grade of liquid smoke is $92 \%$ and \% yield for grade $1^{\text {st }}$ of liquid smoke is $97,22 \%$. GC-MS analysis results that liquid coal smoke has high levels of acetic acid and phenol content. These compounds plays an important role for preservation food and antimicrobial application.
\end{abstract}

Keywords: Liquid Smoke, Coal, Pyrolysis 


\section{Pendahuluan}

Asap cair merupakan hasil kondensasi atau pengembunan dari uap hasil pembakaran yang dapat diperoleh melalui proses pirolisis dari bahan yang mengandung komponen selulosa, senyawa asam, hemiselulosa dan lignin. Asap cair ini kemudian dimurnikan untuk memisahkan senyawa-senyawa kimia yang tidak diinginkan, misalnya senyawa tar yang tidak larut, dengan menggunakan asam piroglinat (Wijaya, 2008) atau dapat juga dilakukan pemurnian menggunakan distilasi dan atau adsorpsi, sehingga asap cair dapat dikelompokkan menjadi grade 1, grade 2 dan 3 yang memiliki fungsi khusus (Fachraniah \& Rahmi, 2009; Sari, dkk., 2009; Rinaldi, A. dkk 2015; Fauzan \& Ikhwanus, 2017). Asap cair grade 3 digunakan pada pengolahan karet dan pengawet kayu agar tahan terhadap rayap, asap cair grade 2 ditujukan sebagai pengawet makanan dengan taste asap dan asap cair grade 1 digunakan sebagai pengawet makanan dengan kualitas yang paling bagus (Fauzan \& Ikhwanus, 2017).

Asap cair memiliki kemampuan berupa sifat antioksidan dan antibakteri yang dapat digunakan untuk mengawetkan bahan makanan dikarenakan adanya senyawasenyawa fenol yang merupakan salah satu komponen aktif dalam asap cair selain karbonil, keton, aldehid, asam-asam, lakton, alkohol, furan, dan ester. Selain itu asap cair juga mampu merubah tekstur pada produk olahan (daging, ikan) dan merubah kualitas nutrisi pada produk olahan (Wijaya, dkk, 2008 dan Sari, 2009).

Berbagai macam bahan baku telah digunakan untuk pembuatan asap cair antara lain sampah organik (Gani, 2007), tempurung kelapa (Edinov dkk, 2013), kelapa sawit, cangkang kelapa sawit, tandan kosong kelapa sawit dan janjang kelapa sawit (Haji, 2013) serta kayu pelawan (Akbar dkk, 2013) dan serbuk gergaji kayu pinus (Wijaya, dkk, 2008). Bahan baku tersebut mengandung cukup kadar hemiselulosa, selulosa dan lignin. Pada penelitian tersebut terungkap adanya hubungan antara jenis bahan baku dan komposisi senyawa pada produk asap cair (Wijaya, dkk, 2008).

Batubara terbentuk dari endapan sisa tumbuhan dengan komponen penyusunnya diperkaya dengan berbagai macam polimer organik seperti karbohidrat, lignin, protein dan lainnya. Potensi sumber daya batubara Indonesia cukup besar yaitu 61,366 miliar ton yang tersebar di 19 daerah provinsi termasuk provinsi Jambi. Produksi batubara di Indonesia didominasi oleh batubara berkalori rendah hingga sedang, mencerminkan cadangan batubara Indonesia yang didominasi oleh jenis lignite dan sub-bituminous (Nugroho, 2017).

Pembuatan asap cair pada penelitian ini dilakukan dengan proses pirolisis dengan menggunakan batubara sub-bituminous. Asap cair yang dihasilkan selanjutnya dimurnikan dengan menggunakan 2 metode yaitu metode adsorpsi dan distilasi sehingga akan terbagi menjadi tiga grade. Kedua proses pemurnian tersebut akan dipilih mana yang paling efektif dalam menghasilkan grade asap cair dengan dilihat berdasarkan kandungan senyawanya terutama kadar keasaman dan kandungan fenolnya serta \% yield yang dihasilkan. 


\section{Metode Penelitian}

\subsection{Alat dan Bahan}

Peralatan yang digunakan pada penelitian ini yaitu reaktor pirolisis, seperangkat alat distilasi, termokopel, batang pengaduk, neraca analitik, corong, pipet tetes, kertas saring, erlenmeyer $1000 \mathrm{~mL}$, gelas beaker $100 \mathrm{~mL}, 500 \mathrm{~mL}, 1000 \mathrm{~mL}$, botol semprot, dan $\mathrm{pH}$ meter.

Bahan yang dibutuhkan pada penelitian ini yaitu batubara, $\mathrm{NaOH}$ o,1 $\mathrm{M}, \mathrm{FeCl} 31 \%$, indicator PP, aquades, zeolite teraktivasi, bentonite tanpa aktivasi, bentonite teraktivasi serta bentonite-limestone (CCBN).

\subsection{Preparasi bahan baku}

Bahan baku berupa batubara dilakukan pengecilan ukuran untuk mempermudah proses pirolisis, setelah dilakukan pengecilan ukuran selanjutnya batubara ditimbang sebanyak $20 \mathrm{Kg}$. Batubara yang sudah ditimbang akan diolah di dalam reaktor pirolisis untuk pembuatan asap cair.

\subsection{Proses Pengolahan Asap Cair}

Batubara yang telah dipreparasi dimasukan kedalam reaktor pirolisis untuk menghasilkan asap. Reaktor pirolisis yang digunakan adalah reaktor yang pernah digunakan pada penelitian Naswir, 2018. Asap dari proses pirolisis akan dikondensasikan untuk menghasilkan asap cair.

\subsection{Pemurnian Asap Cair}

Pemurnian asap cair ditujukan untuk menghilangkan kadar tar yang terdapat di dalam asap cair. Metode yang digunakan yaitu adsorpsi dan distilasi yang akan dibandingkan efektivitasnya. Adsorpsi dilakukan menggunakan zeolite teraktivasi (berdasarkan metode penelitian yang dilakukan oleh Fauzan \& Ikhwanus, 2017), bentonite tanpa aktivasi, bentonite teraktivasi serta bentonite-limestone (CCBN). Sedangkan proses distilasi dilakukan dalam 3 tahap yang sesuai dengan grade yang ingin dicapai, yaitu pada grade 3 distilasi dilakukan pada temperatur $110-120^{\circ} \mathrm{C}$, untuk grade 2 dilakukan proses distilasi pada temperature $130-145^{\circ} \mathrm{C}$, dan grade 1 didistilasi pada temperatur $170-190^{\circ} \mathrm{C}$.

\subsection{Pengukuran Tingkat Keasaman Dalam Asap Cair}

Proses Pengujian Kandungan Asam dalam Asap cair yaitu dengan cara mengukur langsung menggunakan $\mathrm{pH}$ meter.

\subsection{Pengukuran Kandungan Asam Asetat Dalam Asap Cair}

Asap cair yang telah dimurnikan diukur kandungan asam yang terkandung di dalamnya. Pengukuran dilakukan dengan cara titrasi asam-basa menggunakan $\mathrm{NaOH} 1$ M dengan asam asetat sebagai basisnya.

\subsection{Pengujian Kandungan Fenol Dalam Asap Cair}

Asap cair masing-masing grade sebanyak o,5 $\mathrm{ml}$ dilarutkan ke dalam $5 \mathrm{ml}$ aquades, kemudian larutan asap cair dipanaskan dengan menggunakan hot plate sampai panas. Setelah panas di tetesi larutan $\mathrm{FeCl} 3$ 1\% kemudian diamati perubahan warna yang terjadi. 


\section{Hasil Penelitian dan Pembahasan}

\subsection{Proses pembuatan asap cair batubara}

Pada pembuatan asap cair dari bahan baku batubara pada penelitian ini menggunakan batubara jenis sub-bituminous, dikarenakan jenis ini memiliki kadar air yang lebih sedikit jika dibandingkan menggunakan batubara jenis lignit. Proses pembuatan asap cair ini menggunakan metode pirolisis dengan temperatur pirolisis $280-300^{\circ} \mathrm{C}$ dan waktu pirolisis selama 4,5 jam. Kondisi operasi serta karakteristik bahan baku yang digunakan akan berpengaruh terhadap jumlah dan jenis produk yang dihasilkan (Triantoro dkk 2013 dan Prasetiyo dkk 2018 serta Fauziati dkk 2018). Pada proses pirolisis kondensat dari asap cair mulai dihasilkan pada temperature $110^{\circ} \mathrm{C}$ pada waktu 30 menit. Batubara yang digunakan pada penelitian ini sebanyak $20 \mathrm{Kg}$ dan didapatkan hasil kondensat asap cairnya sebanyak 1,6 Liter dengan pH asap cair 3,70. Kemudian asap cair akan dimurnikan untuk mendapatkan asap cair grade 3, grade 2 dan grade 1.

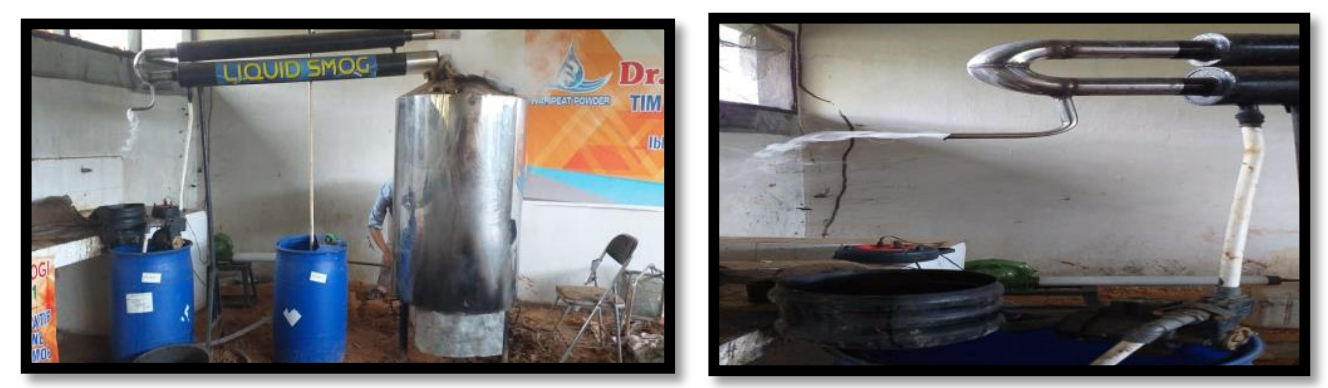

Gambar 1. Proses pembuatan asap cair batubara (kiri), kondensat asap cair batubara (kanan)

\subsection{Pemurnian asap cair}

Pada penelitian ini dilakukan dua metode pemurnian yaitu pemurnian dengan cara adsorpsi dan pemurnian dengan cara distilasi. Metode adsorpsi dilakukan dengan menggunakan beberapa adsorben yaitu: zeolite teraktivasi, bentonite tanpa aktivasi, bentonite teraktivasi serta bentonite-limestone (CCBN). Pemurnian asap cair dengan menggunakan metode adsorpsi kurang tepat dilakukan dikarenakan pada saat uji nilai $\mathrm{pH}$ tidak terjadi penurunan $\mathrm{pH}$. Penurunan $\mathrm{pH}$ pada asap cair merupakan indikasi meningkatnya kandungan asam pada asap cair. Hasil pemurnian asap air menggunakan metode adsorpsi dapat dilihat pada Tabel 1.

Akibat kurang efektifnya pemurnian asap cair menggunakan metode adsorpsi maka dilakukan pemurnian menggunakan metode distilasi. Distilasi dilakukan untuk menghilangkan kandungan pengotor yang terdapat pada asap cair yang bersifat racun seperti kandungan Tar dan Benzo(a)pyrene. Distilasi yang dilakukan menggunakan temperature yang berbeda-beda untuk mendapatkan masing-masing-masing grade.

Asap cair grade 3 didapat dengan melakukan distilasi pada temperature 110$120^{\circ} \mathrm{C}$ dengan waktu distilasi selama 8 jam. Pada distilasi tahap ini berguna untuk menghilangkan kadar Tar dan Benzo(a)pyrene pada asap cair. Benzo(a)pyrene termasuk kedalam salah satu jenis senyawa PAH (Polycyclic Aromatic Hydrocarbon) yang sangat dihindari karena merupakan senyawa pemicu kanker pada manusia dan hewan. Benzo(a)pyrene memiliki rumus molekul $\mathrm{C}_{2} \mathrm{OH}_{12}$ dan berat molekul 252,148 
gram/mol. Senyawa ini meliliki titik didih $495^{\circ} \mathrm{C}$. sehingga untuk pemurnian dari senyawa Benzo(a)pyrene ini didistilasi pada temperature $110-120^{\circ} \mathrm{C}$ dikarenakan pada temperature ini kandunganBbenzo(a)pyerene tidak akan ikut menguap sehingga didapatkan asap cair yang bebas dari senyawa Benzo(a)pyrene. Benzo(a)pyrene dan tar pada temperatur ruangan berbentuk padatan berwarna hitam (lihat gambar $2 a$ ).

Tabel 1. Hasil adsorpsi asap cair menggunakan 4 jenis adsorben

\begin{tabular}{|c|c|c|c|}
\hline Jenis Adsorben & Tampak Fisik & pH & Gambar \\
\hline $\begin{array}{l}\text { Zeolite teraktivasi } \\
\text { asam }\left(\mathrm{H}_{3} \mathrm{PO}_{4}\right)\end{array}$ & $\begin{array}{l}\text { Ketika selesai } \\
\text { disaring larutan } \\
\text { asap cair } \\
\text { menjadi keruh }\end{array}$ & $3-3,5$ & \\
\hline $\begin{array}{c}\text { Bentonite tanpa } \\
\text { aktivasi }\end{array}$ & $\begin{array}{l}\text { Ketika disaring } \\
\text { larutan asap } \\
\text { cair menjadi } \\
\text { bening }\end{array}$ & $3-3,5$ & \\
\hline $\begin{array}{c}\text { Bentonit } \\
\text { teraktivasi asam } \\
\qquad\left(\mathrm{H}_{3} \mathrm{PO}_{4}\right)\end{array}$ & $\begin{array}{l}\text { Ketika disaring } \\
\text { larutan asap } \\
\text { cair menjadi } \\
\text { bening }\end{array}$ & $3-3,5$ & \\
\hline $\begin{array}{c}\text { Bentonite }+ \\
\text { limestone }(\mathrm{CCBN})\end{array}$ & $\begin{array}{c}\text { Ketika disaring } \\
\text { larutan asap } \\
\text { cair menjadi } \\
\text { agak keruh }\end{array}$ & $3-3,5$ & \\
\hline
\end{tabular}
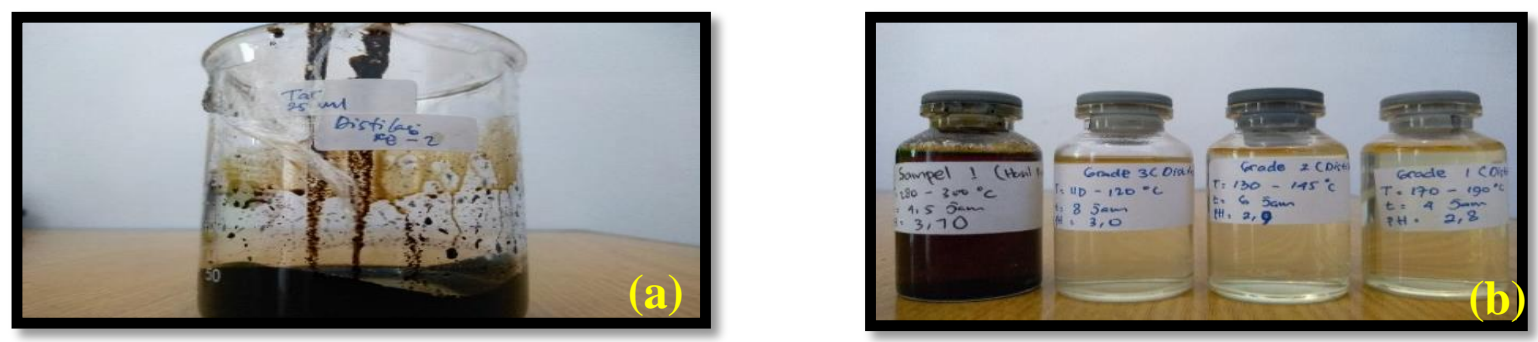

Gambar 2. (a) Senyawa sisa distilasi pada grade 3 (b) Penampilan asap cair pada berbagai grade 
Penampilan asap cair berbagai grade berdasarkan warnanya dapat dilihat pada Gambar 2b. Pada grade 3 didapatkan asap cair berwarna kuning bening tetapi masih berbau asap yang kuat. Warna asap cair menjadi kuning bening ini dikarenakan kandungan tar dan benzo(a)pyrene yang sudah berkurang. Dari $400 \mathrm{ml}$ asap cair hasil pirolisis yang didistilasi didapatkan distilat berupa asap cair grade 3 sebanyak $370 \mathrm{ml}$ dengan $\mathrm{pH}$ yang didapat yaitu 3,0 dan $30 \mathrm{ml}$ berupa kandungan tar dan benzo(a)pyrene sebagai residu, sehingga didapat \% yield dari distilasi grade 3 ini yaitu 92,5\%.

Pada pemurnian asap cair untuk menghasilkan asap cair grade 2 yaitu dengan cara ditilasi pada temperature $130-145^{\circ} \mathrm{C}$ dengan waktu distilasi selama 6 jam. Pada tahap ini destilasi dilakukan untuk menambah perolehan dari asam asetat dan memastikan tidak ada lagi kandungan pengotor seperti tar dan benzo(a)pyrene lagi untuk grade 2 ini. Asap cair yang dihasilkan pada grade ini berwarna kuning bening, tidak berbeda jauh dengan asap cair grade 3, akan tetapi bau asap cair pada grade 2 ini lebih ringan jika dibandingkan pada grade 3. Nilai $\mathrm{pH}$ pada grade 2 ini juga meningkat yaitu 2,90 dikarenakan naiknya kandungan asam pada asap cair grade 2. Dari $250 \mathrm{ml}$ asap cair yang didistilasi pada grade ini didapatkan destilat sebanyak $230 \mathrm{ml}$ dan 20 $\mathrm{ml}$ adalah kandungan tar dan benzo(a)pyrene. Sehingga \% yield yang didapat yaitu $92 \%$.

Asap cair grade 1 didapatkan dengan cara mendistilasi asap cair hasil pirolisis pada temperature $170-190^{\circ} \mathrm{C}$ dengan waktu distilasi selama 4 jam. Tujuan dari distilasi tahap ini yaitu untu meningkatkan perolehan dari kandungan asam dan kandungan fenol pada asap cair sehingga bisa digunakan untuk mengawetkan makanan, selain itu tujuan dari distilasi tahap ini memastikan tidak adanya kandungan senyawa pengotor yang turut dalam grade ini sehingga aman untuk digunakan. Asap cair grade 1 yang dihasilkan memiliki warna lebih bening dari grade lainnya dan memiliki aroma asap yang lebih ringan juga jika dibandingkan dengan asap cair grade di bawahnya. Nilai $\mathrm{pH}$ dari grade ini yaitu 2,8 ini menunjukan bahwa meningkatnya kandungan asam dan kandungan fenol pada asap cair. Dari $180 \mathrm{ml}$ asap cair yang didistilasi didapatkan destilat sebanyak $175 \mathrm{ml}$ dan $5 \mathrm{ml}$ adalah residu berupa tar dan benzo(a)pyrene, sehingga \% yield pada asap cair dari grade ini yaitu 97,22\%.

\subsection{Karakteristik Asap Cair}

Asap cair dari berbagai grade dianalisis untuk mengetahui sifat dan kandungan senyawa apa saja yang terdapat pada asap cair. Analisis yang dilakukan yaitu uji tingkat keasaman $(\mathrm{pH})$, uji kadar asam asetat, uji kualitatif fenol dan terakhir adalah analisis menggunakan instrument GC-MS.

\subsubsection{Uji tingkat keasaman ( $\mathrm{pH})$}

Uji tingkat keasaman ini menggunakan $\mathrm{pH}$ meter yang telah dikalibrasi. Hasil uji keasaman yang ditunjukkan pada grafik di gambar 3 memperlihatkan bahwa semakin semakin tinggi grade asap cair maka tingkat keasamannya akan meningkat pula, hal ini dikarenakan semakin bertambahnya kandungan asam dan fenol pada masingmasing grade asap cair.

\subsubsection{Uji Kadar Asam Asetat}

Uji kadar asam asetat ini dilakukan dengan cara titrasi. Dimana $2 \mathrm{ml}$ asap cair dari berbagai grade diencerkan dengan $100 \mathrm{ml}$ aquades kemudian dititrasi dengan 
larutan $\mathrm{NaOH}$ o,1M dengan ditambahkan indikator $\mathrm{pp}$ hingga larutan asap cair berwarna bayangan merah muda. Dari hasil uji kandungan asam asetat yang ditampilkan pada Tabel 2. didapatkan bahwa semakin tinggi grade asap cair maka kandungan asam asetat akan semakin tinggi pula.

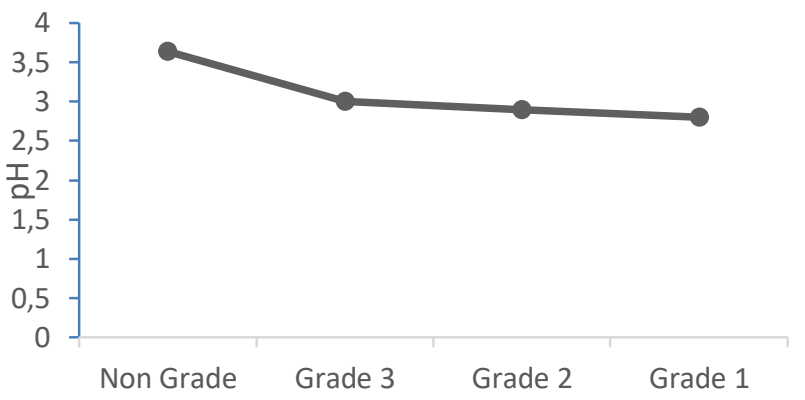

Gambar 3. Tingkat keasaman asap cair pada berbagai grade

\begin{tabular}{cc}
\hline $\begin{array}{c}\text { Grade asap } \\
\text { cair }\end{array}$ & $\begin{array}{c}\text { Jumlah asam } \\
\text { asetat }(\mathrm{mg} / \mathbf{m l}))\end{array}$ \\
\hline Non Grade & 14,4 \\
Grade 3 & 11,4 \\
Grade 2 & 16,2 \\
Grade 1 & 21,6 \\
\hline
\end{tabular}

Tabel 2. Hasil analisa uji kadar asam asetat

\subsubsection{Uji kualitatif Fenol}

Uji kualitatif fenol dilakukan bertujuan untuk mengetahui ada atau tidaknya gugus fungsi fenol pada senyawa asap cair berbagai grade. Uji ini dilakukan dengan cara memasukan 0,5 gram asap cair berbagai grade dengan $10 \mathrm{ml}$ aquades. Larutan ini kemudian dipanaskan dan diteteskan larutan $\mathrm{FeCl}_{3} 1 \%$. Pada saat ditetesi maka dilihat terjadi perubahan pada larutan asap cair berubah menjadi warna hitam. Warna hitam terbentuk karena adanya reaksi antara gugus fenol pada asap cair denga larutan $\mathrm{FeCl}_{3}$ dengan bantuan panas membentuk senyawa kompleks yang memberikan warna hitam pada larutan.

Pada saat pengujian didapatkan hasil bahwa pada asap cair non grade menghasilkan warna hitam pekat yang menandakan adanya kandungan fenol pada asap cair non-grade, pada asap cair grade 1 dan 3 juga menghasilkan warna hitam yang menandakan adanya kandungan fenol dalam asap cair grade ini. Suatu senyawa kompleks dapat berwarna karena adanya transisi elektron dari ion pusat akibat adanya ligan. $\mathrm{Fe}^{3+}$ merupakan ion logam transisi trivalent dengan orbital molekul paramagnetic. Bentuk orbital molekul dari $\mathrm{Fe}^{3+}$ adalah octahedral yang kompleks ikatannya melibatkan ikatan sigma atau ikatan pi dengan ligan (Sahoon, dkk. 2012)

Pada grade 2 menghasilkan warna kuning kecokelatan dikarenakan hasil reaksi dari senyawa asam asetat yang merupakan senyawa dominan di dalam asap cair. Senyawa yang memiliki gugus fungsi karboksilat ( $\mathrm{R}-\mathrm{COOH}$ ) apabila bereaksi dengan $\mathrm{FeCl}_{3}$ akan membuat warna larutan menjadi kuning kecokelatan. Hasil dari uji kualitatif fenol dapat dilihat pada Gambar 4.

\subsubsection{Analisa GC-MS (Gas Chromotography Mass Spectroscopy)}

Asap cair berbagai grade dilakukan pengujian menggunakan alat instrumentasi GC-MS (Gas Chromotography Mass Spectroscopy). Tabel 3 berisikan kandungan senyawa pada asap cair non grade. Pada Tabel 3 dapat dilihat bahwa asap cair batubara memiliki kandungan senyawa penyusun asap cair yaitu asam asetat dan fenol sehingga membuktikan bahwa batubara dapat dijadikan sebagai bahan baku untuk pembuatan 
asap cair. Kadar persen area asam asetat yang terdapat pada asap non-grade yaitu $15,78 \%$ dan untuk fenol yaitu sebesar $8,96 \%$ dan masih terdapat gugus fenol lainnya pada asap cair batubara. Kandungan-kandungan pengotor yang terdapat pada asap cair ini seperti gugus benzen dihilangkan dengan proses distilasi. Kandungan senyawa asap cair dari batubara ini telah sesuai dengan hasil penelitian sebelumnya (Basu, 2010) yang dapat dilihat pada Tabel 4. Perbedaannya tidak terdapat kandungan air pada asap cair dari batubara. Hal ini diduga karena perbedaan besarnya kandungan moisture pada jenis bahan baku yang digunakan, diketahui pada literatur biomassa yang digunakan adalah kayu yang memiliki moisture content sebesar 30\%-90\% sedangkan kandungan moisture pada batubara 25\%-30\% sehingga kandungan air tidak terdapat pada asap cair batubara jenis sub-bituminous.

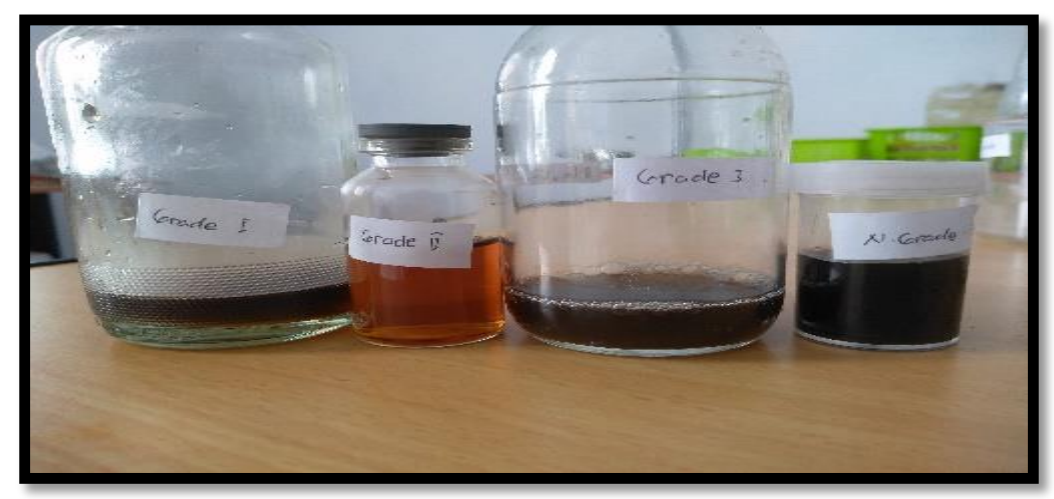

Gambar 4. Hasil Analisa Gugus Fenol Asap Cair

Tabel 3. Senyawa-senyawa pada asap cair non grade

\begin{tabular}{|c|c|c|c|c|c|}
\hline \multicolumn{6}{|c|}{ Sampel 1} \\
\hline Nama Senyawa & $\begin{array}{c}\% \\
\text { Area }\end{array}$ & $\mathbf{R T}$ & $\begin{array}{l}\text { Rumus } \\
\text { Molekul }\end{array}$ & $\begin{array}{c}\text { Berat } \\
\text { Molekul } \\
\text { (gram/mol) }\end{array}$ & $\begin{array}{l}\text { Rumus } \\
\text { Struktur }\end{array}$ \\
\hline Acetaldehyde (CAS) & 2,49 & 1,397 & $\mathrm{C}_{2} \mathrm{H}_{4} \mathrm{O}$ & 44,05 & \\
\hline $\begin{array}{c}\text { Tetramethylammonium } \\
\text { perchlorate }\end{array}$ & 0,33 & 1,614 & $\mathrm{C}_{4} \mathrm{H}_{12} \mathrm{ClNO}_{4}$ & 173,59 & $\begin{array}{r}\mathrm{CH}_{3} \\
\mathrm{I} \\
\mathrm{CH}_{3}-\mathrm{N}^{+}-\mathrm{C} \\
\mathrm{I} \\
\mathrm{CH}_{3}\end{array}$ \\
\hline Acetic Acid (CAS) & 15,78 & 1,824 & $\mathrm{C}_{2} \mathrm{H}_{4} \mathrm{O}_{2}$ & 60,052 & \\
\hline $\begin{array}{l}\text { 2-Propanone, } 1 \\
\text { Hydroxy }\end{array}$ & 1,66 & 1,915 & $\mathrm{C}_{3} \mathrm{H}_{6} \mathrm{O}_{2}$ & 74.079 & \\
\hline $\begin{array}{c}2(3 \mathrm{H})-\text { Furanone, } \\
\text { dihydro/ Butyrolactone }\end{array}$ & 0,34 & 3,469 & $\mathrm{C}_{4} \mathrm{H}_{6} \mathrm{O}_{2}$ & 86.090 & \\
\hline Phenol & 8,96 & 4,155 & $\mathrm{C}_{6} \mathrm{H}_{6} \mathrm{O}$ & 94.113 & \\
\hline $\begin{array}{l}\text { Cyclohexanol, 4- } \\
\text { methyl-(CAS) }\end{array}$ & 0,89 & 4,435 & $\mathrm{C}_{7} \mathrm{H}_{14} \mathrm{O}$ & 114.19 & \\
\hline $\begin{array}{l}\text { 2-Cyclopenten-1-one, } \\
\text { 2-hydroxy-3-methyl }\end{array}$ & 1,81 & 4,540 & $\mathrm{C}_{6} \mathrm{H}_{8} \mathrm{O}_{2}$ & 112,13 & \\
\hline
\end{tabular}




\begin{tabular}{|c|c|c|c|c|}
\hline $\begin{array}{l}\text { Phenol, 2-methoxy- } \\
\text { (CAS) }\end{array}$ & 0,94 & 5,115 & $\mathrm{C}_{7} \mathrm{H}_{8} \mathrm{O}_{2}$ & 124,14 \\
\hline Cyclobutanol (CAS) & 8,07 & 5,255 & $\mathrm{C}_{4} \mathrm{H}_{8} \mathrm{O}$ & 72,11 \\
\hline 3-Pyridinol & 1,12 & 5,402 & $\mathrm{C}_{5} \mathrm{H}_{5} \mathrm{NO}$ & 95,1 \\
\hline 1,2-Benzenediol & 15,03 & 6,480 & $\mathrm{C}_{6} \mathrm{H}_{6} \mathrm{O}_{2}$ & 110,112 \\
\hline $\begin{array}{l}\text { 1,2-Benzenediol, 3- } \\
\text { methoxy }\end{array}$ & 3,96 & 6,725 & $\mathrm{C}_{7} \mathrm{H}_{8} \mathrm{O}_{3}$ & 140,14 \\
\hline $\begin{array}{l}\text { 1,2-Benzenediol,3- } \\
\text { methyl }\end{array}$ & 2,06 & 6,991 & $\mathrm{C}_{7} \mathrm{H}_{8} \mathrm{O}_{2}$ & 124,14 \\
\hline $\begin{array}{l}\text { 1,2-Benzenediol,4- } \\
\text { methyl }\end{array}$ & 3,02 & 7,425 & $\mathrm{C}_{7} \mathrm{H}_{8} \mathrm{O}_{2}$ & 124,14 \\
\hline Phenol,2,6-dimethoxy & 6,26 & 7,579 & $\mathrm{C}_{8} \mathrm{H}_{10} \mathrm{O}_{3}$ & 154,16 \\
\hline $\begin{array}{l}\text { 1,3-Benzenediol, 5- } \\
\text { methyl-(CAS) }\end{array}$ & 0,89 & 7,915 & $\mathrm{C}_{7} \mathrm{H}_{8} \mathrm{O}_{2}$ & 124,14 \\
\hline $\begin{array}{l}\text { 3,5-Dimethyl-2-furyl } \\
\text { methyl ketone }\end{array}$ & 1,65 & 8,133 & $\mathrm{C}_{8} \mathrm{H}_{10} \mathrm{O}_{2}$ & 138,16 \\
\hline $\begin{array}{c}\text { 3-Hydroxy-4- } \\
\text { methoxybenzoic acid }\end{array}$ & 3,01 & 8,399 & $\mathrm{C}_{8} \mathrm{H}_{8} \mathrm{O}_{4}$ & 168,15 \\
\hline $\begin{array}{c}\text { Ethyl 3- } \\
\text { hydroxybenzoate }\end{array}$ & 1,11 & 8,826 & $\mathrm{C}_{9} \mathrm{H}_{10} \mathrm{O}$ & 166,17 \\
\hline $\begin{array}{l}\text { 2- Methoxy-6- } \\
\text { methylaniline }\end{array}$ & 3,13 & 9,134 & $\mathrm{C}_{8} \mathrm{H}_{11} \mathrm{NO}$ & 137,18 \\
\hline D-Allose & 11,06 & 9,659 & $\mathrm{C}_{6} \mathrm{H}_{12} \mathrm{O}_{6}$ & 180,16 \\
\hline
\end{tabular}

Tabel 4. Kandungan asap cair dari pirolisis kayu (Basu, 2010)

\begin{tabular}{|c|c|}
\hline Major Group & Compounds \\
\hline Water & \\
\hline Lignin fragments & Insoluble pyrolytic lignin \\
\hline Aldehydes & $\begin{array}{l}\text { Formaldehyde, acetaldehyde, } \\
\text { hydroxyacetaldehyde, glyoxal, methylglyoxal }\end{array}$ \\
\hline Carboxylic acid & $\begin{array}{l}\text { Formic, acetic, propionic, butyric,pentanoic, } \\
\text { hexanoic, glycolic }\end{array}$ \\
\hline Carbohydrates & $\begin{array}{l}\text { Cellobiosan, } \alpha \text {-D-levoglucosan, oligosaccharides, } \\
1,6 \text { anhydroglucofuranose }\end{array}$ \\
\hline $\begin{array}{l}\text { Phenols } \\
\text { Furfurals }\end{array}$ & Phenol, cresols, guiacols, syringols \\
\hline Alcohols & Methanol, ethanol \\
\hline Ketones & $\begin{array}{l}\text { Acetol (1-hydroxy-2-propanone), } \\
\text { cyclopentanone }\end{array}$ \\
\hline
\end{tabular}


Pada hasil analisa di Tabel 5 menunjukkan bahwa asap cair grade 3 memiliki kadar pengotor yang sedikit dikarenakan hasil distilasi dengan kandungan asam asetat sebanyak 39,57\% dan fenol sebanyak 33,88\%. Pada grade 3 ini terjadi peningkatan jumlah asam asetat dan fenol ini sesuai dengan percobaan sebelumnya. Asam asetat dan fenol inilah yang nantinya akan dijadikan senyawa yang berguna sebagai penggumpal lateks.

Kemudian pada asap cair grade 2 (lihat Tabel 6) kandungan asam asetat meningkat menjadi $69,57 \%$ dan fenol menjadi $20,15 \%$ dan tidak terdapat lagi senyawasenyawa tar dan PAH (polycyclic Aromatic Hydrocarbon) sehingga aman untuk proses pengasapan ikan menggunakan asap cair grade 2 dari pirolisis batubara. Tingginya kandungan asam asetat pada grade ini menjadikan asap cair dapat digunakan sebagai pengawet pada ikan dan kandungan fenolnya sebagai antibakteri.

Pada asap cair grade 1 (lihat Tabel 7) persen area asam asetat adalah $58,44 \%$ dan fenol sebanyak $27,24 \%$ sehingga asap cair grade 1 bisa digunakan sebagai pengawet makanan karena tidak adanya kandungan pengotor pada asap cair, selain itu berdasarkan penelitian (Fauzan dan Ikhwanus, 2017) bahwa kandungan-kandungan pada asap cair grade 1 dan 2 bisa digunakan sebagai pengawet dan antimikroba yang mengandung senyawa-senyawa yaitu asam dan turunannya (format, asetat, butirat, propional, metil ester); alkohol (metil, etil, propil, alkil dan isobutil alkohol); aldehid (formaldehida, asetaldehida, furfural, dan metil furfural); hidrokarbon (silene, kumene dan simene); keton (aseton, metil etil keton, metil propil keton dan etil propil keton); fenol serta piridin dan metil piridin.

Tabel 5. Senyawa-senyawa pada asap cair grade 3

\begin{tabular}{|c|c|c|c|c|c|}
\hline \multicolumn{6}{|c|}{ Grade 3} \\
\hline Nama Senyawa & $\begin{array}{c}\% \\
\text { Area }\end{array}$ & RT & $\begin{array}{l}\text { Rumus } \\
\text { Molekul }\end{array}$ & $\begin{array}{c}\text { Berat } \\
\text { Molekul } \\
\text { (gram/mol) }\end{array}$ & Rumus Struktur \\
\hline $\begin{array}{l}\text { 2- Butanamine,3- } \\
\text { methyl- (CAS) }\end{array}$ & 4,68 & 1,404 & $\mathrm{C}_{5} \mathrm{H}_{13} \mathrm{~N}$ & 87,16 & \\
\hline $\begin{array}{c}1- \\
\text { Heptadecanamine }\end{array}$ & 1,65 & 1,607 & $\mathrm{C}_{17} \mathrm{H}_{37} \mathrm{~N}$ & 255,48 & \\
\hline Acetic Acid (CAS) & 39,57 & 1,908 & $\mathrm{C}_{2} \mathrm{H}_{4} \mathrm{O}_{2}$ & 60,052 & \\
\hline $\begin{array}{l}\text { 2-Propanone, 1- } \\
\text { hydroxy- (CAS) }\end{array}$ & 4,47 & 2,006 & $\mathrm{C}_{3} \mathrm{H}_{6} \mathrm{O}_{2}$ & 74.079 & \\
\hline $\begin{array}{l}\text { Propanoic acid } \\
\text { (CAS) }\end{array}$ & 1,43 & 2,153 & $\mathrm{C}_{3} \mathrm{H}_{6} \mathrm{O}_{2}$ & 74.079 & \\
\hline Furfural & 1,46 & 2,818 & $\mathrm{C}_{5} \mathrm{H}_{4} \mathrm{O}_{2}$ & & \\
\hline Phenol (CAS) & 33,88 & 4,212 & $\mathrm{C}_{6} \mathrm{H}_{6} \mathrm{O}$ & 94.113 & \\
\hline Phenol, 2-methyl & 1,75 & 4,947 & $\mathrm{C}_{7} \mathrm{H}_{8} \mathrm{O}$ & & \\
\hline $\begin{array}{c}\text { Phenol, 2- } \\
\text { methoxy-(CAS) }\end{array}$ & 2,43 & 5,164 & $\mathrm{C}_{7} \mathrm{H}_{8} \mathrm{O}_{2}$ & 124,14 & \\
\hline
\end{tabular}




\begin{tabular}{ccccc}
\hline $\begin{array}{c}\text { Benzenemethanol } \\
\text { (CAS) }\end{array}$ & 3,49 & 5,234 & $\mathrm{C}_{7} \mathrm{H}_{8} \mathrm{O}$ & 108.140 \\
$\begin{array}{c}\text { 2-Methoxy-4- } \\
\text { methylphenol }\end{array}$ & 1,47 & 6,193 & $\mathrm{C}_{8} \mathrm{H}_{10} \mathrm{O}_{2}$ & 138,16 \\
$\begin{array}{c}\text { Phenol, 2,6- } \\
\text { dimethoxy }\end{array}$ & 1,73 & 7,769 & $\mathrm{C}_{8} \mathrm{H}_{10} \mathrm{O}_{3}$ & 154,16 \\
\hline
\end{tabular}

Tabel 6. Senyawa-senyawa pada asap cair grade 2

\begin{tabular}{|c|c|c|c|c|c|}
\hline \multicolumn{6}{|c|}{ Grade 2} \\
\hline Nama Senyawa & $\begin{array}{c}\% \\
\text { Area }\end{array}$ & RT & $\begin{array}{l}\text { Rumus } \\
\text { Molekul }\end{array}$ & $\begin{array}{c}\text { Berat } \\
\text { Molekul } \\
\text { (gram/mol) } \\
\end{array}$ & Rumus Struktur \\
\hline $\begin{array}{c}\text { 2- } \\
\text { Heptanamine, } \\
\text { 6-methyl- } \\
\text { (CAS) }\end{array}$ & 6,58 & 1,390 & $\mathrm{C}_{8} \mathrm{H}_{19} \mathrm{~N}$ & 129.24 & $\mathrm{H}_{2}$ \\
\hline $\begin{array}{l}\text { Acetic Acid } \\
\text { (CAS) }\end{array}$ & $\begin{array}{c}69,5 \\
7\end{array}$ & 1,670 & $\mathrm{C}_{2} \mathrm{H}_{4} \mathrm{O}_{2}$ & 60,052 & \\
\hline $\begin{array}{c}2(3 \mathrm{H})- \\
\text { Furanone, } \\
\text { dihydro- (CAS) }\end{array}$ & 2,75 & 3,582 & $\mathrm{C}_{4} \mathrm{H}_{6} \mathrm{O}_{3}$ & 102 & \\
\hline Phenol & $\begin{array}{c}20,1 \\
5\end{array}$ & 4,296 & $\mathrm{C}_{6} \mathrm{H}_{6} \mathrm{O}$ & & 4.113 \\
\hline $\begin{array}{l}\text { Phenol, 2,6- } \\
\text { dimethoxy- } \\
\text { (CAS) }\end{array}$ & 0,95 & 7,867 & $\mathrm{C}_{8} \mathrm{H}_{10} \mathrm{O}_{3}$ & 154,16 & \\
\hline
\end{tabular}

Tabel 7. Senyawa-senyawa pada asap cair grade 1

\begin{tabular}{|c|c|c|c|c|c|}
\hline \multicolumn{6}{|c|}{ Grade 1} \\
\hline Nama Senyawa & $\begin{array}{c}\% \\
\text { area }\end{array}$ & RT & $\begin{array}{c}\text { Rumus } \\
\text { Molekul }\end{array}$ & $\begin{array}{c}\text { Berat Molekul } \\
\text { (gram/mol) }\end{array}$ & $\begin{array}{c}\text { Rumus } \\
\text { Struktur }\end{array}$ \\
\hline 2-Butanamine (CAS) & 0,66 & 1,404 & $\mathrm{C}_{4} \mathrm{H}_{11} \mathrm{~N}$ & 73.139 & \\
\hline Acetic Acid (CAS) & 58,44 & 2,272 & $\mathrm{C}_{2} \mathrm{H}_{4} \mathrm{O}_{2}$ & 60,052 & \\
\hline $\begin{array}{l}\text { 2-Propanone, 1- } \\
\text { hydroxy }\end{array}$ & 7,22 & 2,335 & $\mathrm{C}_{3} \mathrm{H}_{6} \mathrm{O}_{2}$ & 74.079 & \\
\hline Pyridine (CAS) & 0,41 & 2,615 & $\mathrm{C}_{5} \mathrm{H}_{5} \mathrm{~N}$ & 79.102 & \\
\hline $\begin{array}{l}\text { 3-Furanol, } \\
\text { tetrahydro }\end{array}$ & 0,74 & 2,678 & $\mathrm{C}_{4} \mathrm{H}_{8} \mathrm{O}_{2}$ & 88.11 & \\
\hline Phenol (CAS) & 27,24 & 4,233 & $\mathrm{C}_{6} \mathrm{H}_{6} \mathrm{O}$ & 94.113 & \\
\hline
\end{tabular}




\begin{tabular}{ccccc}
\hline $\begin{array}{l}\text { 2-Cyclopenten-1-one, } \\
\text { 2-hydroxy-3-methyl }\end{array}$ & 1,25 & 4,646 & $\mathrm{C}_{6} \mathrm{H}_{8} \mathrm{O}_{2}$ & 112,13 \\
$\begin{array}{c}\text { Phenol, 2-methoxy } \\
\begin{array}{c}\text { Phenol, 2,6- } \\
\text { dimethoxy }\end{array}\end{array}$ & 0,89 & 5,143 & $\mathrm{C}_{7} \mathrm{H}_{8} \mathrm{O}_{2}$ & 124,14 \\
\hline
\end{tabular}

\section{Kesimpulan}

Metode pemurnian asap cair batubara yang baik adalah menggunakan metode distilasi karena menghasilkan pH yang lebih optimal dibandingkan metode adsorpsi. Dari berbagai uji yang dilakukan terhadap asap cair komponen terbesar yang dimiliki oleh asap cair batubara yaitu senyawa asam asetat dan fenol sehingga asap cair yang dihasilkan dari pirolisis batubara sub-bituminous dapat digunakan untuk proses pengawetan dan antimikroba.

\section{Daftar Pustaka}

Akbar, A., Paindoman, R., \& Coniwanti, P. (2013). Pengaruh variabel waktu dan temperatur terhadap pembuatan asap cair dari limbah kayu pelawan (Cyanometra cauliflora). Jurnal Teknik Kimia, Vol 19 No. 1, 1-8.

Basu, P. (2010). Biomassa Gasification and Pyrolysis Practical Design and Theory, Elsevier, New York.

Edinov, S., Indrawati, Y., Refilda. (2013). Pemanfaatan Asap Cair Tempurung Kelapa Pada Pembuatan Ikan Kering dan Penentuan Kadar Air, Abu Serta Proteinnya, Jurnal Kimia Unand, 2 (2) : 29-35.

Fachraniah, Fona, Z., \& Rahmi. (2009). Peningkatan Kualitas Asap Cair dengan Distilasi. Jurnal Reaksi, Vol. 7(14),1-11.

Fauzan, \& Ikhwanus, M. (2017). Pemurnian Asap Cair Tempurung Kelapa Melalui Destilasi dan Filtrasi Menggunakan Zeolit dan Arang Aktif. Seminar Nasional Sains dan Teknologi 2017, 1-5.

Fauziati, dkk. (2018). Pengaruh Berbagai Suhu Pirolisis Asap Cair Dari Cangkang Sawit Sebagai Bahan Penggumpal Lateks. Jurnal Riset Teknologi Industri. Vol.12 No.2.

Gani, A. (2007). Konversi Sampah Organik Pasar Menjadi Komarasca (Kompos, arang aktif dan asap cair) dan Aplikasinya pada Tanaman Daun Dewa. Disertasi Program Doktor.

Haji, A.G. (2013). Komponen Kimia Asap Cair Hasil Pirolisis Limbah Padat Kelapa Sawit. Jurnal Rekayasa Kimia dan Lingkungan. Vol 9 No.3.

Naswir, M. (2018). Teknologi 3 in 1 Pembuatan Asap Cair Biochar dan Limestone. Fakultas Teknik. Universitas Jambi

Nugroho, Hanan. (2017). Batu Bara Sebagai Pemasok Energi Nasional ke Depan: Apa yang Perlu Disiapkan?. Jurnal Perencanaan Pembangunan. Vol 1 No 1. 
Prasetiyo, T., \& dkk. (2018). Studi Pencairan Batu Bara (Coal Liquefaction) Metode Pirolisis Pada Batu Bara Peringkat, Kabupaten Kutai Kartanegara Provinsi Kalimantan Timur. Jurnal Teknologi Mineral FT UNMUL, Vol.6 No.2 p.21-28.

Rinaldi, A. dkk (2015). Pemurnian Asap Cair dari Kulit Durian. Jurnal Molekul, 112-120.

Sahoo, B., Nayak, N.C., Samataray, A. dan Pujapanda, P.K. (2012). Inorganic Chemistry. PHI Learning Pvt. Delhi.

Sari, T. I., \& dkk. (2009). Proses Pembuatan Asap Cair (Liquid Smoke) Dari Limbah Industri. Jurnal Teknik Kimia, Vol.16, No.2, 44-47.

Triantoro, A., \& dkk. (2013). Pengaruh Agen Gasifikasi Batu bara Terhadap Produk Gas yang Dihasilkan Oleh Batu bara Peringkat Rendah. Jurnal Keilmuan dan Aplikasi Teknik, Vol. 14, No.2, p. 201-210.

Wijaya, M., Noor, E., Irawadi, T. T., \& Pari, G. (2008). Perubahan Suhu Pirolisis Terhadap Struktur Kimia Asap Cair Dari Serbuk Gergaji Kayu Pinus. Jurnal Ilmu dan Teknologi Hasil Hutan, 73-77. 